\title{
The Effect of Healthcare Service Quality, Hospital Image and Experience Economic on Worth of Mouth through BPJS Patient PerceptionType B Hospital in West Java
}

\author{
Darnus Djaya , Farida Jasfar, Hamdy Hady \\ willy.arafah@gmail.com
}

Abstract: The aim of this study was to examine the direct and indirect effects of health care service quality, hospital image, economic experience, word of mouth (WOM) communication through seeing patients. In addition, the role of patients as mediators and their relational consequences will also be tested.The model proposed in this study was tested using Structural Equation Model (SEM). Data were collected from a sample of 302 patients Badan Penyelenggara Jaminan Sosial (BPJS members), questionnaires about experience, which were experienced directly by the research target.This research found that the image of the hospital, economic experience, and the perception of the patients had a direct impact on WOM communication. While the quality of health services must be mediated by the perception of patients to influence WOM communication or must be arranged simultaneously with the hospital image, economic experience, and patient perceptions. Therefore hospital management must carry out the quality of hospital services along with managing the hospital image and applying the concept of economic experience so as to build patient perceptions and ultimately create WOM communication in patients.

Keywords: Healthcare Service Quality, Hospital Image, Experience Economic, Patient Perception, WOM.

\section{INTRODUCTION}

Decree of the Minister of Health of the Republic of Indonesia No. 983 / Men. Kes / SK / XI / 1992 states that the Hospital is one of the public sector organizations engaged in health services. Republic of Indonesia Law No. 44 of 2009 concerning hospitals states that the Regional General Hospital (RSUD) is a hospital owned and managed by the local government. RSUD must compete with private hospitals that have already been prepared with the demands of professional services. Indonesia, like other developing countries, develops social security based on funded social security, which is stipulated in Law No.24, 2011 concerning Social Security Organizing Bodies. Regulation of Health minister No. 56, 2014 categorizes Indonesian hospitals in two classifications of hospitals seen from the types of services provided, namely public hospitals and special hospitals. Public hospitals are hospitals that serve patients with the public. Consists of type A, type B, type C and type D.

Type B Hospital is a type of hospital classified by the regulation of the health minister as regulated in PMK 340 of 2010 as a hospital that has limited specialist and subspecialty service facilities. This type B hospital was established in every capital city in each district. This hospital receives referrals from the surrounding district hospitals. Type B hospital is named the Regional General Hospital. The difference between type B hospitals and other types of hospitals is the facilities and capabilities of medical services. Type B hospitals must have at least four basic specialist medical services, four medical support specialist services, eight other specialist medical services and two basic subspecialty medical services. Regulation of Health Minister no. 340, 2010 clause 10 and 11, explained that type B hospitals must have medical service facilities and capabilities, wich adjusted to above classification. According to Ministry of Health data in 2018, there are 68 type B hospitals that are categorized as type B hospitals in West Java, which also serve patients in the Health Social Security Administering Agency (BPJS-Health) 
The Effect of Healthcare Service Quality, Hospital Image and Experience Economic on Worth of Mouth through BPJS Patient PerceptionType B Hospital in West Java

The Health Social Security Administering Body (BPJS - Health) is a legal entity established to organize health programs (Health BPJS Regulation Number 1 Year 2014). The Government of Indonesia is responsible for providing health protection and facilities for the people of Indonesia in accordance with Presidential Regulation No.28 of 2016 concerning health insurance, which contains provisions on the amount of health insurance contributions and benefits of accommodation. The implementation of the BPJS by the hospital is not without constraints, it is funded socially, makes BPJS a non-profit service, this is a challenge in itself how hospital management manages the best services for BPJS participants.

Health care institutions face similar competitive challenges today, as do other service institutions in the field of customers who demand high quality services at competitive prices and are delivered with courtesy and consistency (Obamiro, Ogunnaike, \& Osibanjo, 2014). Health care is now patient-centered, where emphasis is placed on customer-oriented marketing (Thoa et al., 2013). So that special efforts must be made by hospital management, so that they can compete in the health service industry.

The higher level of quality of hospital services, has a significant positive effect on patient loyalty, which is mediated by patient satisfaction (Amin \& Nasharuddin, 2013); (Shabbir et al., 2016), perceptions of peer-to-peer quality significantly affect patient satisfaction that will affect patient loyalty (Choi et al., 2013). Another aspect, positive image helps in attracting and retaining patients and achieving hospital performance, determining community perceptions in health care services (Obamiro et al., 2014); (Cham et al., 2016); (Narang et al., 2015).

A challenge for government hospitals as BPJS service providers, to be able to provide good services so that it becomes a treatment option for the community, especially BPJS participants. This is a very important problem for BPJS health which aims to meet the needs of the community in terms of health insurance which in fact is far from satisfying participants' expectations (Jansen et al., 2009). Therefore it needs to be explored more deeply about the factors in patient behavior, namely service quality, hospital image and economic experience of patients influencing WOM through patient perceptions, so that it will give more benefits to the health industry, especially in non-profit services such as BPJS.

\section{THEORETICAL FRAMEWORK}

\section{Healthcare Service Quality}

First time suggested by Donabedian (1980) that the quality of health care services is the application of medical science and technology in a way that maximizes its benefits to health without increasing risk reveals, the quality of health care services is the difference between customer perceptions and their expectations about hospitals offering these services. The literature review on the quality of health services reveals that service quality has been influenced by a number of factors that focus on improving service quality. These factors depend on the type of service sector, needs, type of respondent, socio-demographic background of stakeholders, culture and beliefs (Akhade et al, 2016).

Service Quality can be defined as how far the difference between reality and customer expectations for the service they receive or get (Debata et al., 2015). Health care services are products that are intangible and cannot be physically touched, felt, seen, counted or measured by the goods processed (Mosadeghrad, 2013). In health care, it becomes far more important. A doctor's diagnosis and treatment can only be effective if certain information is obtained from the patient to allow the doctor to know the patient's disease, in this way appropriate care can be given (Owusu Kwateng et al., 2017).

Service quality is usally evaluated in terms of technical quality and functional quality ( Gronroos,C., 1984). In the world of health, technical quality is defined on the basis of the technical accuracy of medical diagnoses and procedures or professional specification compliance, the competence of staff when they perform their routines. 
The Effect of Healthcare Service Quality, Hospital Image and Experience Economic on Worth of Mouth through BPJS Patient PerceptionType B Hospital in West Java

Functional quality, patients usually depend on functional aspects (facilities, cleanliness, quality of hospital food, attitudes of hospital employees) rather than technical aspects, this shows that technical quality is not a useful measure to describe how patients evaluate the quality of medical services (Edura Wan Rashid et al., 2009). In addition, the perception of individual health also depends on psychological well being which is certainly not directly related to physical condition (Polsa et al., 2013)

The essence of the concept of service quality is to show all forms of actualization of service activities that satisfy people who receive services in accordance with responsiveness, foster assurance, show tangible evidence that can be seen, according to empathy from people who provide services in accordance with their reliability carry out the service tasks that are given consequently to satisfy those who receive services.

Parasuraman, (1988) suggested the concept of service quality related to satisfaction is determined by five elements commonly known as the quality of service "RATER" (responsiveness, assurance, tangible, empathy and reliability). Researchers in the health service sector have used a Service Quality scale with dimensions of tangibles, reliability, responsiveness, assurance, empathy (Abuosi, et al., 2013; Mosadeghrad, 2013; Alan Edward Baldwin, 2014; Debata et al., 2015; Zarei, 2015; Jandavath Anand Byram, et al., 2016; Campos, et al., 2016; Owusu Kwateng, et al., 2017; Ahmed, et al., 2017; Hapsari, et al., 2017).

\section{Hospital Image}

In the health care context, Obamiro, et al., (2014) suggested that hospital brand image is not absolute; but comparable among competing hospitals. Patients see the image of the hospital starting at the time of arrival, treatment experience until departure. Agood perception of hospital brand image is a major source of competitive advantage and therefore a valuable strategic asset that is directly related to hospital performance.

Nurses have a major role in shaping the image of health care, (Saunders, et al., 2012). His research describes the image of nurses with three measurements, namely brand image scale, nursing current brand position scale and nursing desire brand position scale, determining how much the nurse profession can create a good image in the context of health care.

Kemp, et al., (2014) have examined how consumer brand relationships with health care organizations and illustrate that brands inspire unique meanings for consumers and personal meanings and experiences with these brands can create an emotional connection between consumers and brands. Similarly, service providers have adopted a branding strategy in health care marketing. Health care is an intimate and emotional service experience that plays an integral role in health care decision making.

Cham, et al., (2016) focused his research on medical customer satisfaction and behavioral intentions based on how they felt the image of the hospital they had visited and the services provided. Specifically, this aims to examine (1) the factors that influence hospital brand image, (2) the relationship between hospital brand image and service quality, and (3) the relationship between service quality, patient satisfaction, and behavioral intention.

\section{Experience Economic}

Economic experience is things that relate to one's experience in consuming a product (Pine \& Gilmore, 1998); (Oh, Fiore, \& Jeoung, 2007) formulating the economic experience as a matter of background to the customer's consumption pattern.

The term Economic Experience was first popularized by Pine \& Gilmore (1998) and its development has become the most important global trend in the economic context (Mehmetoglu \& Engen, 2011). In any context, consumers today tend to rely on their choices based on experience, including education, entertainment, beauty, 
The Effect of Healthcare Service Quality, Hospital Image and Experience Economic on Worth of Mouth through BPJS Patient PerceptionType B Hospital in West Java

and the desire to escape from restraints. Experience economic background of consumers in economic behavior (Chang S, 2018).

\section{Patient Perception}

Perception can also be interpreted as the process of an individual choosing, organizing and interpreting information inputs to create a meaningful picture about the world (Kotler, 1994). Perception is generally formed from phenomena, needs, desires, values and experiences (Dian, et al., 2017). Perception as an impression obtained by an individual through the five senses is then analyzed, interpreted and then evaluated, so that the individual obtains meaning (Robbins,2003). Perception is generally formed from phenomena, needs, desires, values and experiences (Dian, et al., 2017). In the context of the world of health, the patient's perception is the thought of various stimulants received by patients to evaluate a health service (Edward Baldwin, 2014).

Nikoloski, et al., (2013) found evidence that the age and socio-economic status, and to some extent, gender, act as a major determinant of individual perceptions of the quality of health care. In addition, there is also strong evidence of the impact of non-linear age on perceived quality of health care. The analysis provides evidence of a positive relationship between transparency and the quality of health care. In other words, in countries with higher public sector transparency and lower corruption, the general public seems more satisfied with the quality of health care services. More importantly, perceptions of the possibility of being harmed by medical errors are increasing in more unequal countries, which suggests the possibility of inadequate access to health care, and especially for quality health care, for lower socioeconomic groups. (Nikoloski , et al., 2013).

Edward Baldwin, (2014) in examining the relationship between service quality practices and the results of service quality in dental care found that patients 'fears and anxieties, patient appreciation of services that were comfortable and timely, patient involvement in treatment were found to significantly influence patients' perceptions of dental care. This shows many things that can affect the patient's perception of the quality of health services. One of the factors that influence the patient's perception is the environment, family or the nearest circle (Sajidin, 2011). Perception is also determined by the patient's knowledge and understanding of the structure, processes and results of service products that reach the community (Kobayashi et al., 2011).

Measurement of patient perceptions that have been carried out by previous researchers with the structure approach dimension, proccess approach, outcome approach (Kobayashi, et al., 2011); service quality, atmosfherics, product quality, behavioral intention (Ha, et al., 2012); individual social experience, variable macro level (Nikoloski, et al., 2013); perception of hospital image (Kartika, et al., 2013); perception of medical report (Dang, et al., 2014); trust, perception of healthcare quality (Arboleda Arango, 2015); perception of communication, perception of cure (Ejaz, et al., 2016); perception of physicians care, perception of nurses care, perception of supporting staff, perception operational activities, perception of physical maintenance (Shabbir, et al., (2016); perception of servqual, perception of product, perception of customer loyalty (Putra, et al., 2017); perception of healthcare quality dimension (Duku, et al., 2018).

\section{Word of Mouth (WOM)}

WOM communication is interpersonal communication that occurs between individuals one with another individual based on the experience of each individual to a good company or product in the form of goods or services (Siverman, 2001 ) WOM communication as an interpersonal communication that is effective in influencing a person's attitude such as in conveying information about products or services (Hughes, 2005)

Personal communication channels in the form of speech or WOM can be an effective promotional method because generally delivered from consumers by consumers and for consumers, so that consumers or satisfied customers can become advertising media for companies. (Wu \& Wang, 2011). WOM is a communication process 
The Effect of Healthcare Service Quality, Hospital Image and Experience Economic on Worth of Mouth through BPJS Patient PerceptionType B Hospital in West Java

in the form of giving recommendations both individually and in groups to a product or service that aims to provide personal information (Kotler and Keller, 2012).

Trust, reference influence and corporate social responsibility are key variables in building affective commitment in consumer brand relationships in the context of health care. After affective commitment is reached, consumers can identify the health care provider brand and a self-branding connection is formed. When such phenomena occur, consumers can function as supporters for brands by actively promoting them through WOM communication (Kemp et al., 2014).

From a practical and academic perspective, the realization of word-of-mouth communication through the creation of a customer experience is highly dependent on the customers involved. On the one hand, in practice, social media marketing strategies have changed from increasing size of the fan base to focusing on starting customers who are more actively involved (Zhang et al., 2016).

Previous research in the period 2010 to 2018 with the object of health industry research, service quality and outcomes has been the focus of research, but few studies have examined how service quality, hospital image and patient economic experience affect WOM through patient perceptions, in the health care industry, namely hospitals

\section{CONCEPTUAL FRAMEWORK \& RESEARCH HYPOTHESIS}

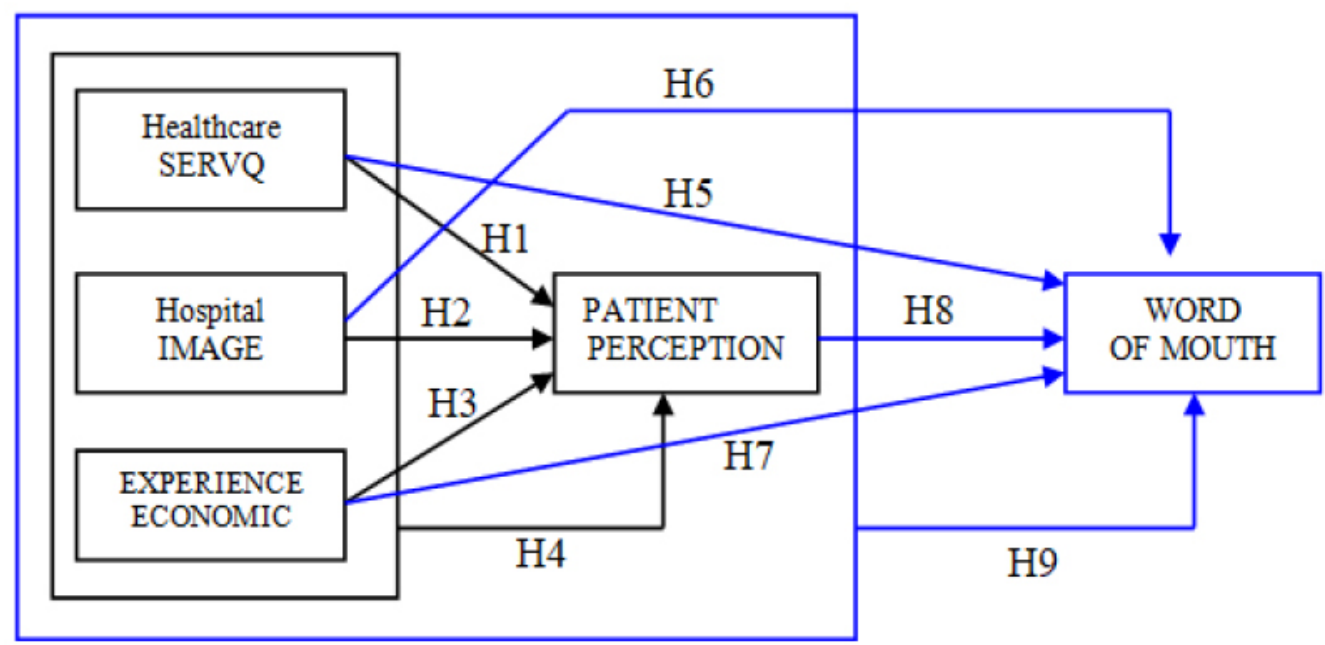

Based on literature studies and previous research related to variables, then hypotheses are :

\section{H1: Healthcare Service Quality has a Positive Effect on Patient Perception}

Service quality has a strong influence on consumer perceptions. This is stated in the study Bouzaabia et al., (2013); Ha et al., (2012). The relationship between service providers, search-service, quality of facilities and interaction with support staff has a positive effect on customer perceptions (Kondasani et al., 2015). Service quality affects the perception of Bank customers in the population (Hinson et al., 2011)

\section{H2: Hospital Image has a Positive Effect on Patient Perception}

Company image that is built, can create perceptions on consumers (Hinson etal., 2011). Health care qualifications received by patients, builds the patient's perception of hospitals and services, both for public and private hospital services (Shabbir et al., 2016). In the context of BPJS hospitals and services, the image of the hospital and the services provided are likely to influence the patient's perception of hospitals and BPJS services. 
The Effect of Healthcare Service Quality, Hospital Image and Experience Economic on Worth of Mouth through BPJS Patient PerceptionType B Hospital in West Java

\section{H3: Experience Economic aas a Positive Effect on Patient Perception}

Economic experience consisting of, personal experience, education, esthetic, and escaping, will affect consumer perceptions of a service so that it creates stronger or weaker intentions on consumer behavior. (Manthiou et al., 2014). Experience Economic can influence customer opinion on a product or service (Lupton, 2013). Experience Economic as a phenomenon of shifting public consumption trends that affect people's perception of an item (Mehmetoglu et al., 2011). In the context of tourism, experience economy plays a role in the perception of tourists and will produce behaviors desired by tourism providers (Oh, et al., 2007).

\section{H4: Healthcare Service, Hospital Image, Experience Economic Simultaneously Effect on Patient Perception}

Healthcare Service Quality, has been shown to influence patient perceptions in their interactions, (Bouzaabia et al., 2013) and (Ha et al., 2012). The quality of health services received by patients builds patients' perceptions of hospitals and services, both for public and private hospital services (Shabbir et al., 2016). While in his research (Lupton, 2013) illustrates that experience economics can affect customer opinion on a product or service. This raises the opinion that simultaneously, Healthcare Service, Hospital Image and Experience Economic will affect the patient's perception in their interactions with the hospital.

\section{H5: Healthcare Service Quality has a Positive Effect on Wom Communication}

Healthcare Service Quality will affect WOM. Service Quality results in consumer behavior, one of which is WOM communication (Choudhury, 2014). Product quality, personal interaction, phsycal environment quality, and perceived value influence WOM behavior directly or indirectly through relationship quality (Jalilvand et al., 2017).Every dimension of the quality of health care services can affect patient behavior, which at the end is producing WOM communication (Byram, 2016). Service quality has the strongest effect on influencing customer behavior, including WOM communication (Koteswara Rao Kondasani et al., 2015).

\section{H6: Hospitalimage has a Positive Effect on Wom Communication}

A well-built corporate image will leave a good impression on consumers, if managed properly will build consumer behavior, including positive WOM communication. Hospital images can help hospitals achieve organizational goals, including patient behavior, namely WOM communication (Cham et al., 2016). Trust, influence of reference and corporate social responsibility are key variables in building affective commitment in consumer brand relationships in the context of health care. After the affective commitment is reached, consumers can identify the brand of health care providers and self brand connections are formed (Kemp, et al., 2014). When such phenomena occur, consumers can function as support for the hospital by actively promoting it through WOM communication. (Hapsari, et al., 2017).

\section{H7: Experience Economichas a Positive Effect on Wom Communication}

The experience economy dimension is education experience, entertainment experience, escapist economy and estetics experience, optimal experience has a positive effect on customer memory freshness (Manthiou et al., 2014). Memory customers will cause the customer's desire to communicate with others about the experience experienced with the product or service.

\section{H8: Patient Perception has a Positive Effect on Wom Communication}

Consumer perceptions abouta service / company will build consumer behavior to carry out WOM communication both positively and negatively in accordance with the perception generated, and the desire to repurchase the service. (Dian et al., 2017). The influence of overall services results in perceptions of customers, and subsequently results in customer satisfaction and WOM communication to customers (Sivadas et al., 2017). 
The Effect of Healthcare Service Quality, Hospital Image and Experience Economic on Worth of Mouth through BPJS Patient PerceptionType B Hospital in West Java

H9: Healthcare Service Quality, Hospital Image, Experience Economic and Perception Simultaneously Effect on Wom Communication

Hospital service quality has an effect on patient satisfaction and patient intention behavior. (Koteswara Rao Kondasani et al., 2015). Service Quality produces consumer behavior, one of which is WOM communication (Choudhury, 2014). Consumers can function as support for hospitals promoting it through WOM communication. "(Kemp et al., 2014). Meanwhile, Manthiou et al., (2014) revealed that the experience economy dimension has a positive effect on and will lead to WOM communication to customers. Perception can affect customer WOM communication (Sivadas et al., 2017). With the results of previous studies, it is possible that these four variables will simultaneously affect the value of WOM communication.

\section{RESEARCH METHODS}

Research design is all the processes carried out in planning and conducting research (Sekaran and Bougie, 2013).This research is a quantitative research which by testing the hypothesis, aims to obtain the influence of the independent variables on the dependent variable. This study will examine in depth about the effect of the influence of variables in the unit of analysis. As for the unit of analysis is the organization in this case the type B Hospital in the Province of West Java with the object of research is the BPJS participants

Healthcare service quality is the patient's assessment of health care services sought by health care providers. Measurement of Healthcare service quality with tangibles and indicators dimensions Tan1, Tan2, Tan3, Tan4, Tan5; reliability and indicators are Rel1, Rel2, Rel3, Rel4; Responsiveness and indicators are Res1, Res2, Res3, Res4; Assurance and indicators are ASS1, ASS2, ASS3, ASS4; Empathy and the indicators are Emp1, Emp2, Emp3, Emp4; Accountability and indicators Acc1, Acc2, Acc3.

Hospital image is a representation of the overall perception of the hospital which is formed from an evaluation of information or experience when interacting with the hospital. Measurement of hospital image with indicators of personal experience (HIM1), practicability (HIM2) and brand symbolic (Him3, Him4, Him5). Experience economic is an experience as an economic consideration that underlies a person in making decisions in the context of service, can also be called consumer consumption patterns. Economic experience is measured by Education indicators (Exp1), Esthethic (Exp2, Exp3), Entertaint (Exp4, Exp5), Escapism (Exp6, Exp7), Commercial Reason (Exp8) and Media Reason (Exp9).

Patient perception is a thought that is related to stimulants (color, sound, feeling) received or felt by patients, which leads to an assessment of a service measured by BPJS participants' perception of patients on quality healthcare service (Ppe1), Hospital Image (Ppe2) and Experience Economy (Ppe3).

WOM is a personal communication as a form of response to services received, with the aim of influencing and recommending a product or service, measured by the indicators Topics (Wom1), Tools (Wom2), Taking parts (Wom3) and Tracking (Wom4).

\section{Population, Sample and Data Collection Method}

The population of this study was all BPJS patients of public hospitals of type B area in West Java Province as many as 68 hospitals spread in 27 regencies of the city. The selection of six samples with purposive sampling, hospitals that have the same criteria that meets the maximum requirements as a type B hospital which are: RSUD Kota Bekasi, RSJP Cimahi, RSUD Sayang Cianjur, RSU Dr. Salamun Bandung, RSUD Sumedang and RSUD Karawang. Data collection 45 item questionnaire survey to respondents selected by convinience sampling method. The distribution of questionnaires was carried out to obtain valid and reliable primary data. Respondents' answers were scored with a 1 to 5 Likert scale. From the spread of 330 questionnaires, 302 questionnaires could be used.

American Research Journal of Business and Management Page 7 
The Effect of Healthcare Service Quality, Hospital Image and Experience Economic on Worth of Mouth through BPJS Patient PerceptionType B Hospital in West Java

Analysis unit were Type B Regional General Hospital in West Java Province and BPJS participant was observation unit. Subjects were asked to rate items from various factors as antecedents of wom namely healthcare quality service, hospital image and experience economic mediated patient perception, in terms of their perception based on a five-point scale (likert). Data analysis proceesed with structural equationmodeling using LISREL 8.80 software. To ensure adequate words for the questionnaire (Oppenhein, 1996), tests were conducted on thirty respondents and practical interviews, after modifications were made before the actual data collection.

\section{Data Analysis Methods}

Data analysis used descriptive statistical analysis and analysis of Structural Equation Models (SEM). The reason for using SEM in this study is that SEM has the ability to estimate the relationships between variables that are multiple and SEM has the ability to describe the pattern of relationships between latent constructs and manifest variables.

\section{RESULT}

Analysis of the respondent's profile is based on the data obtained in the first part of the questionnaire. Questionnaires were distributed to 330 respondents who were BPJS patients at the sample hospital, and obtained data as many as 302 respondents.They were RSUD Bekasi with 50 respondents, then RSUD Karawang with 54 respondents; RSUD Sumedang with 52 respondents; RSJP Cimahi with 50 respondents; RSUD SayangCianjur with 46 respondents; and RSU Dr. Salamun Bandung with a respondent of 50 people.

Table1. Patient Profile

\begin{tabular}{|c|c|c|c|}
\hline \multicolumn{4}{|l|}{ Jenis Kelamin } \\
\hline & Frequency & Percent & Valid Percent \\
\hline Male & 147 & 48,7 & 48,7 \\
\hline Female & 155 & 51,3 & 51,3 \\
\hline Total & 302 & 100,0 & 100,0 \\
\hline \multicolumn{4}{|l|}{ Occupation } \\
\hline & Frequency & Percent & Valid Percent \\
\hline Government employees & 28 & 9,3 & 9,3 \\
\hline Private employees & 52 & 17,2 & 17,2 \\
\hline BUMN employees & 11 & 3,6 & 3,6 \\
\hline Entrepreneur & 47 & 15,6 & 15,6 \\
\hline Others & 164 & 54,3 & 54,3 \\
\hline Total & 302 & 100,0 & 100,0 \\
\hline \multicolumn{4}{|l|}{ Age } \\
\hline & Frequency & Percent & Valid Percent \\
\hline $17-24$ yo & 33 & 10,9 & 10,9 \\
\hline $25-34$ yо & 60 & 19,9 & 19,9 \\
\hline $35-49$ уо & 84 & 27,8 & 27,8 \\
\hline $50-64$ уо & 102 & 33,8 & 33,8 \\
\hline$>65$ уо & 23 & 7,6 & 7,6 \\
\hline Total & 302 & 100 & 100 \\
\hline
\end{tabular}

Source : Data Analysis, 2018 
The Effect of Healthcare Service Quality, Hospital Image and Experience Economic on Worth of Mouth through BPJS Patient PerceptionType B Hospital in West Java

Responden profile showed that based on gender, it is known that the majority of respondents in this study were 155 (51.3\%) people and 147 men (48.7\%) of the total respondents. Based on age, out of a total of 302 respondents aged 17-24 years old as many as 33 people (10.9\%); aged 25 - 34 years old as many as 60 people (19.9\%); aged 35 - 49 years old as many as 84 people (27.8\%); aged 50-64 years old as many as 102 people $(33.8 \%)$ and aged $>65$ years old as many as 23 people (7.6\%). And of the total 302 respondents worked other occupation 164 people (54.3\%); then Private Employees were 52 people (17.2\%); Entrepreneurs are 47 people (15.6\%); Government employees were 28 people (9.3\%) and BUMN employees were 11 people (3.6\%).

\section{Hipothesis Testing Result}

This studies analysis was conducted using approach measurement model analysis, to intended to see construct validity and reliability and structural model analysis, to see the relationship between constructs.

\section{Validity and Reliability}

Validity test with item analysis or items with Corrected Item-Total Correlation correlation and reliability estimation with Alpha-Cronbach formula. Instrument test results as follows:

Table2. Instumen quality test result

\begin{tabular}{|l|c|c|c|c|}
\hline \multicolumn{1}{|c|}{ Variabel } & Butir & Corrected Item-Total Correlation & Cronbach's Alpha & Conclusion \\
\hline SERVQ & 24 & $0,383-0,756$ & 0,916 & Valid and Reliabel \\
\hline HIMAGE & 5 & $0,457-0,607$ & 0,74 & Valid and Reliabel \\
\hline EXECO & 9 & $0426-0,757$ & 0,856 & Valid and Reliabel \\
\hline PERCEPTION & 3 & $0,476-0,743$ & 0,787 & Valid and Reliabel \\
\hline WOM & 4 & $0,477-0,785$ & 0,823 & Valid and Reliabel \\
\hline
\end{tabular}

Source: data analysis, 2018

Instrumen quality testing abobe shows that out of 24 items to measure the Healthcare Service Quality (SERVQ) variable has a value of Corrected Item-Total Correlation in the range of 0.383 - 0.756 and Cronbach's Alpha of 0.916; 5 items to measure Hospital Image (HIMAGE) variables have the value of Corrected Item-Total Correlation in the range of 0.457 - 0.607 and Cronbach's Alpha of 0.740; 9 items to measure the Experience Economic (EXECO) variable have the value of Corrected Item-Total Correlation in the range of $0.426-0.757$ and Cronbach's Alpha of 0.856; 3 items to measure the variable Patient Perception (PERCEPTION) have a value of Corrected Item-Total Correlation in the range of $0.476-0.743$ and Cronbach's Alpha of 0.787; 4 items to measure variables Word of Mouth (WOM) has the value Corrected Item-Total Correlation in the range of 0.477 - 0.785 and Cronbach's Alpha of 0.823 where the value of Corrected Item-Total Correlation is greater than the cut-off value of 0.361 for respondents $n=30$ and the real level $\alpha=0.05$ and the Cronbach's Alpha limit value is 0.60 , thus all items are declared valid and reliable.

\section{GOODNESS OF FIT TEST}

To measure the validity and reliability of construct, an analysis is carried out using Confirmation Factor Analysis (CFA). Table 4 shows that all constructs have met the valid and reliable criteria, where Variance Extracted (VE) and Composite Reliability (CR) are used to evaluate the measurement model. The scale of the items used to measure constructs is presented in Table 4. The convergent validity value is indicated by the size of the loadings factor. The CR value is greater than 0.70 (Fornell C. and Larcker, D., 1981). 
The Effect of Healthcare Service Quality, Hospital Image and Experience Economic on Worth of Mouth through BPJS Patient PerceptionType B Hospital in West Java

Table3. Statistical estimationHybrid Full Model (Goodness of Fit)

\begin{tabular}{|l|c|c|}
\hline \multicolumn{1}{|c|}{ Statistics } & Model Result & Criteria \\
\hline$\chi^{2} / \mathrm{df}(\mathrm{p})$ & $837.31 / 284(0.000)$ & $\mathrm{p}>0,05$ atau $\mathrm{p}>0,10$ \\
\hline GFI; AGFI & $0.93 ; 0.91$ & $0,90-0,95$ \\
\hline CFI; IFI & $0.95 ; 0.95$ & $>0,95$ \\
\hline RMSEA & 0.079 & $<0.080$ \\
\hline NFI; RFI & $0.93 ; 0.91$ & $0,90-0,95$ \\
\hline
\end{tabular}

Source: data analysis, 2018

Table 3 shows an objective estimate which shows that all parameters of the model match meet the requirements of goodness of fit in the analysis using Structural Equation Model (SEM) except Chi-square.

\section{Full SEM Model}

The full SEM equation model with LISREL 8.80 obtained two models, namely the standard model and the $\mathrm{t}$-values model. Based on the model, an SEM Full Model measurement model is performed for each variable.

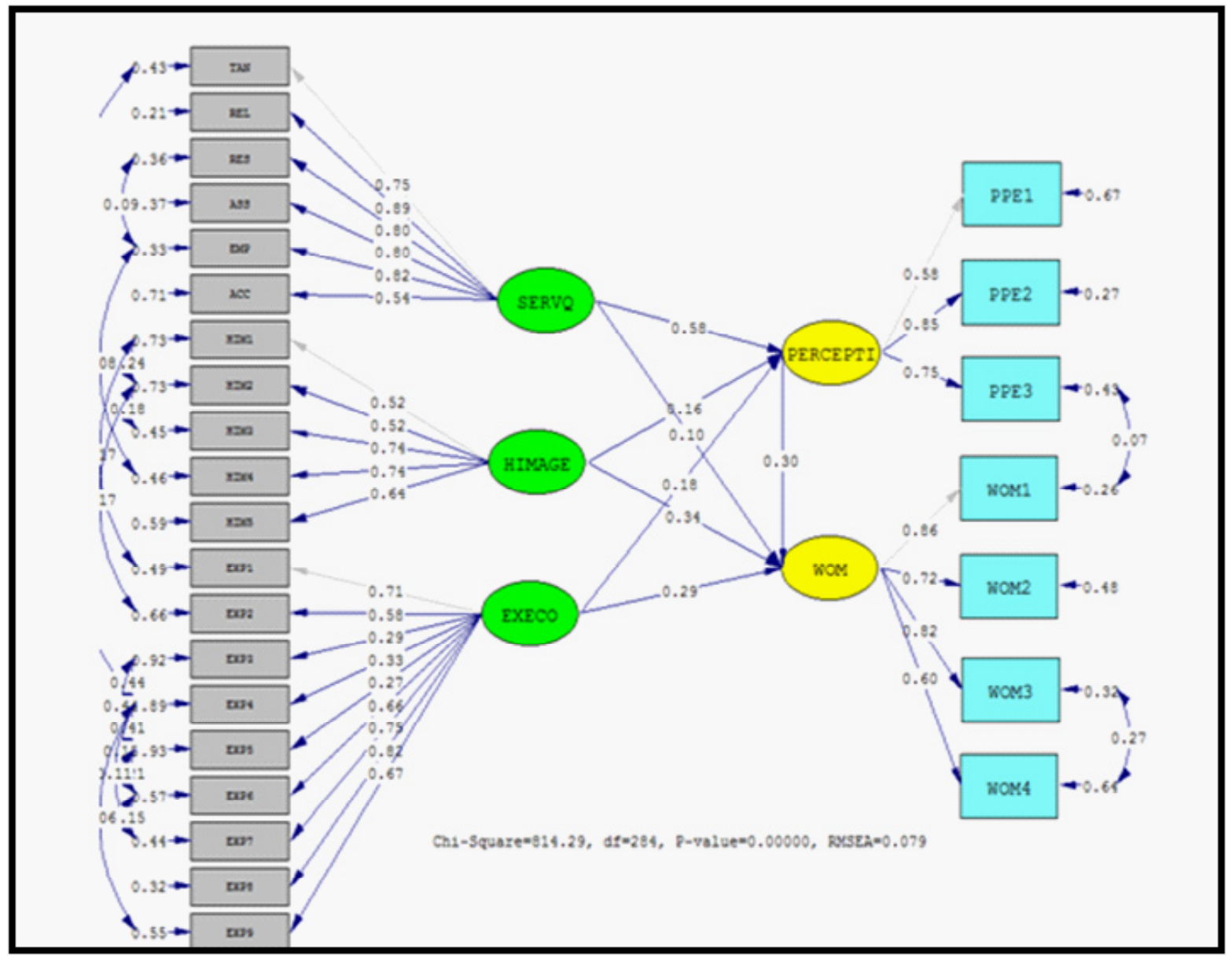

Picture2. Full SEM Model

Source : Lisrel 8.80, 2018 
The Effect of Healthcare Service Quality, Hospital Image and Experience Economic on Worth of Mouth through BPJS Patient PerceptionType B Hospital in West Java

This research hypothesis is testing by using structural equations. Partial influence test with $t$ test while simultaneous test with $\mathrm{F}$ test.

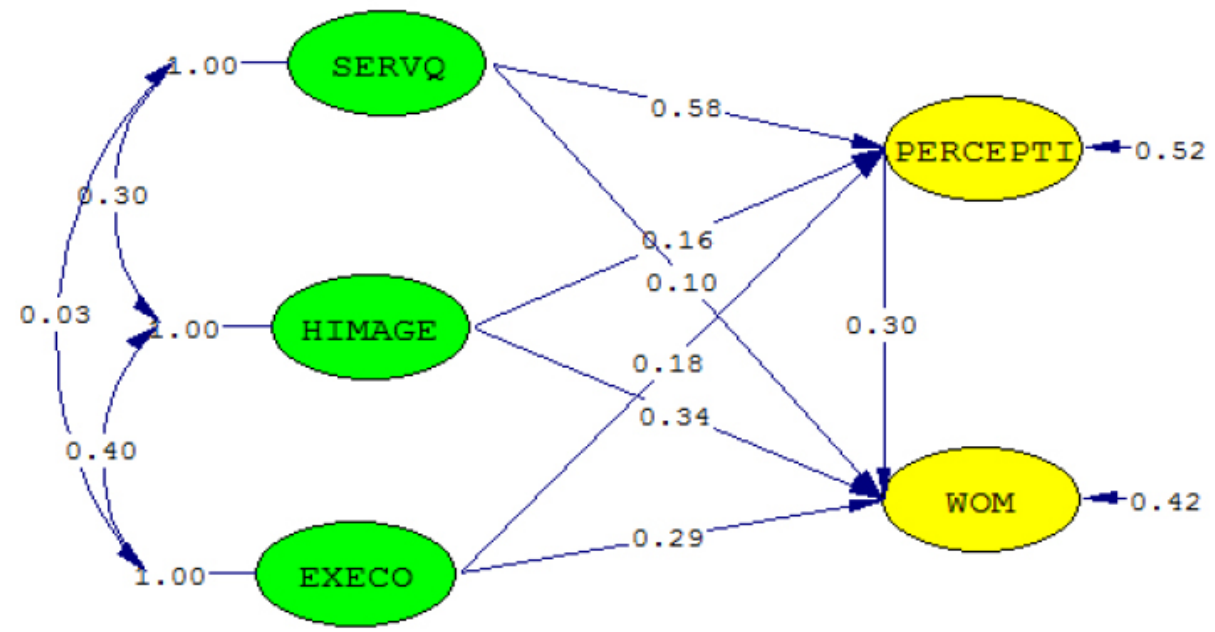

Picture3. Structural Full Model Path diagraminStandardized Solution

\section{The Result of Hypothesis Testing ARE}

\section{H1: There is an Influence of Healthcare Service Quality on Patient Perception}

The results of testing the first hypothesis $\mathrm{H} 1$ proven (accepted) shown by healthcare service quality has a positive and significant effect on patient perception.

Descriptive analysis shows that healthcare service quality has an average value of 3.91, which means that overall respondents have a doubtful perception that they tend to agree to healthcare service quality. Where the average dimensions of the highest healthcare service quality is 4.05 for responsiveness and the lowest average is 3.60 for accountability, then patient perception has an average value of 3.96, meaning that the whole respondents feel hesitant about agreeing to Patient Perception. The highest average for experience economy perception is 3.99, the lowest is hospital image perception at 3.93.

Then overall based on a full model analysis, the dominant dimension of healthcare service quality is Reliability, while the dominant patient perception is the perception of hospital image.

From the results of the analysis and testing of these hypotheses, it can be explained that the quality of service at the Hospital influences the patient's perception positively and significantly.

The results of this research are in line with the research that has been carried out by (Bouzaabia et al., 2013) on, "Retail logistics service quality: a cross cultural survey on Customer perceptions" and (Ha et al., 2012) in his research "The effects of dining atmospherics on behavioral intentions through quality perception ".

\section{H2: There is a Hospital Image Influence on Patient Perception}

Testing the hypothesis $\mathrm{H} 2$ shows that hospital image has a positive and significant effect on Patient perception.

Descriptive analysis shows the hospital image has an average value of 3.93 which means that overall respondents are hesitant to agree with the hospital image. Where the highest average is 4.08 for indicators of practicability and the lowest average is 3.69 for symbolic brand indicators, then patient perception has an average value 
The Effect of Healthcare Service Quality, Hospital Image and Experience Economic on Worth of Mouth through BPJS Patient PerceptionType B Hospital in West Java

of 3.96, which means that the respondents feel doubtful about agreeing with patient perception. The highest average for experience economy perception is 3.99, the lowest average hospital image perception is 3.93.

Then overall based on full model analysis, the dominant indicator of hospital image is brand symbolic, while the dominant indicator of patient perception is hospital image perception.

From the results of the analysis and testing of the hypothesis, it can be explained that the Hospital's image influences the patient's perception positively and significantly.

The results of this study are in line with research conducted by (Hinson et al., 2011) and (Shabbir et al., 2016) which also states a positive relationship between image and perception.

\section{H3: There is an Influence Experience Economic on Patient Perception}

The results of testing the $\mathrm{H} 3$ hypothesis show that experience economy has a positive and significant effect on patient perception.

Descriptive analysis shows that economic experience has an average value of 3.49 which means that the whole respondents are doubtful about the economic experience. Where the highest average is 3.89 for the Education indicator while the lowest average value is 3.21 in the media reason statement, then the patient perception has an average value of 3.96, meaning that the whole respondents feel doubtful about agreeing to Patient Perception. The highest average is experience economy perception at 3.99, the lowest is Hospital Image Perception at 3.93.

Then overall based on full model analysis, the dominant dimension of economic experience is commercial reason, while the dominant dimension of patient perception is the perception of hospital image.

From the results of the analysis and testing of the hypothesis it can be explained that the perception of hospital patients is significantly affected by the patient's economic experience.

The results of this study are in line with the research that has been done by (Manthiou et al., 2014), (Mehmetoglu et al., 2011) and (Oh et al., 2007) in various contexts, and also proven in the context of health services.

H4: There is an Influence of Healthcare Service Quality, Hospital Image and Experience Economy Simultaneously on Patient Perception

The testing results of the $\mathrm{H} 4$ hypothesis show that healthcare service quality, hospital image and experience economic simultaneously have a significant effect on patient perception with a coefficient of determination of $48 \%$. Whereas in the partialy, the variable healthcare service quality, hospital image and experience economy also have a significant influence on patient perception. The most dominant influence in building patient perceptions is the variable healthcare service quality, while the weakest influence on perception is hospital image.

From the results of the analysis and testing of the hypothesis it can be explained that quality of service, hospital image and experience economic simultaneously can shape the perception of BPJS patients in type B hospitals.

The results of this study are in line with the research that has been done by (Bouzaabia et al., 2013), (Ha et al., 2012), (Shabbir et al., 2016) and (Lupton, 2013) which states that perception can be influenced by quality service, hospital image and experience economic.

\section{H5: There is Influence of Healthcare Service Quality on WOM}

The results of testing the hypothesis $\mathrm{H} 4$ indicate that healthcare service quality has a positive and insignificant influence on WOM.

American Research Journal of Business and Management

Page 12 
The Effect of Healthcare Service Quality, Hospital Image and Experience Economic on Worth of Mouth through BPJS Patient PerceptionType B Hospital in West Java

Descriptive analysis shows that healthcare service quality has an average value of 3.91 which means that overall respondents have a doubtful tend to agree to healthcare service quality. Where the average dimensions of the highest healthcare quality service is 4.05 for responsiveness and the lowest average is 3.60 for accountability, then WOM has an average value of 3.80, which means that the respondents doubt tend to agree with WOM. Where the highest average is 3.89 for topics, while the lowest average value is the tracking dimension at 3.66.

Then overall based on a full model analysis, the dominant of healthcare service quality is Reliability, while the dominant dimension of WOM is topics.

From the results of the analysis and testing of the hypothesis it can be explained, that the quality of hospital services directly does not significantly affect the WOM communication of patients.

The results of this research are not in line with research conducted by Choudhury (2014), (Jalilvand et al., 2017), Byram (2016) and (Koteswara Rao Kondasani et al., 2015) which states that service quality can directly affect WOM communication significant.

\section{H6: Hospital Image Influences on WOM}

The results of testing the $\mathrm{H} 6$ hypothesis showed that hospital image had a positive and significant influence on WOM.

Descriptive analysis shows that hospital image has an average value of 3.93 which means that all respondents doubt tend to agree with hospital image. Where the highest average is 4.08 for indicators of practicability and the lowest average is 3.69 for brand symbolic indicators, then WOM has an average value of 3.80 , which means that the respondents doubt tend to agree with WOM. Where the highest average is 3.89 for the topics indicator, while the lowest average value is tracking at 3.66.

Then overall based on full model analysis, the dominant dimension of hospital image is practicability and brand symbolic, while the dominant dimension of WOM is topics.From the results of the analysis and hypotheses testing it can be explained that in BPJS patients in Type B Hospital, the image of the hospital can be affect the patient's WOM communication.

The results of this research are in line with the research that has been conducted by (Hapsari et al., 2017), (Cham et al., 2016) and (Kemp et al., 2014) which has stated that corporate image can influence WOM communication.

\section{H7: There is an Influence of the Experience Economic on WOM}

The results of testing the $\mathrm{H} 7$ hypothesis showed that hospital image had a positive and significant effect on WOM.

Descriptive analysis shows that experience economics has an average value of 3.49 which means that the whole respondents are hesitant with experience economic. Where is the highest average of for the education indicator at 3.89, while the lowest average value is in the media reason statement at 3.21. Then WOM has an average value of 3.80, which means that the respondents doubt tend to agree with WOM. Where the highest average is 3.89 for the topics indicator, while the lowest average value is the tracking statement at 3.66.

Then overall based on the full model analysis, dominant dimension of experience economical is the commercial reason, while the dominant dimension of WOM is topics.From the results of the analysis and testing of these hypothesis it can be explained that in BPJS patients in type B hospitals, WOM communication is significantly influenced by the experience economic felt by patients when interacting with the hospital. 
The Effect of Healthcare Service Quality, Hospital Image and Experience Economic on Worth of Mouth through BPJS Patient PerceptionType B Hospital in West Java

The results of this study are in line with the research that has been carried out by (Manthiou et al., 2014) which stated previously that experience economic affects the customer WOM communication.

\section{H8: There is the Influence of the Patient Perception on WOM}

The results of testing the hypothesis H8 show that patient perception has a positive and significant influence on WOM.

Descriptive analysis shows that patient perception has an average value of 3.96, which means that overall respondents doubt tend to agree with patient perception. Where is the highest average is 3.99 for the experience economy perception while the lowest average value is 3.93 for perception of hospital image. Then WOM has an average value of 3.80 which means that the whole respondents doubt tend to agree with WOM. Where is the highest average is 3.89 for the topics, while the lowest average value is for tracking at 3.66.

Then overall based on full model analysis, the dominant dimension of patient perception is hospital image perception, while the dominant dimension of WOM is topics.From the results of the analysis and testing of these hypothesis it can be explained that WOM communication of BPJS patients in Type B Hospital is significantly influenced by perceptions felt by patients when interacting with the Hospital.

The results of this research are in line with the research that has been done by (Dian et al., 2017) and (Sivadas et al., 2017) which has stated previously a positive and significant relationship between perception and WOM communication.

\section{H9: There is Simultaneously Influence of Healthcare Service Quality, Hospital Image, Experience Economy and Patient Perception with WOM}

The results of the hypothesis $\mathrm{H} 9$ testing show that healthcare service quality, hospital image, experience economy and patient perception simultaneously have a significant effect on WOM with a coefficient of determination of $58 \%$ and in part a fourth variable healthcare service quality, hospital image, experience economy and patient perception also has a significant influence on WOM. From the results of the analysis and testing of these hypothesis it can be explained that in patients with BPJS in hospital type B, service quality, hospital image, experience economic and patient perceptions can encourage patients to WOM communication.

The results of this research are in line with the research that has been done by (Choudhury, 2014), (Kemp et al., 2014) and (Sivadas et al., 2017) that good WOM communication can be influenced by service quality, image, experience economy and perception customer.

\section{Mediator Variable Analysis}

Analysis step of PERCEPTION mediator variable by calculating the amount of direct and indirect influence of SERVQ, HIMAGE, EXECO on WOM and its significance value with t-value. The results of the analysis (1) the direct influence of SERVQ on WOM is not significant, SERVQ indirect effect on WOM with significant PERCEPTION mediation, then the role of PERCEPTION as full mediator influences SERVQ on WOM. (2) the direct effect of HIMAGE on WOM was significant, the indirect effect of HIMAGE on WOM mediated by PERCEPTION was significant, then the role of PERCEPTION as a partial mediator influences HIMAGE on WOM. (3) the direct effect of EXECO on WOM is significant, the indirect effect of EXECO on WOM is mediated by PERCEPTION is significant, then the role of PERCEPTION as a partial mediator of EXECO influence on WOM.

\section{CONCLUSION}

In general, the results of this research can be concluded that healthcare service quality, hospital image and experience economy simultaneously can build BPJS patients' perceptions to communicate WOM after interacting 
The Effect of Healthcare Service Quality, Hospital Image and Experience Economic on Worth of Mouth through BPJS Patient PerceptionType B Hospital in West Java

with type B hospitals in West Java. The most dominant variable in shaping patient perceptions is healthcare service quality, while the smallest variable of its dominance in shaping perceptions is hospital image. While experience economics is the most dominant variable directly affecting WOM communication.

While directly, healthcare service quality is found not significantly affect to WOM communication, but must be mediated by patient perceptions.

\section{Theoretical and Managerial Implications}

The theoretical implications of this study are found hospital image and experience economy and patient perception simultaneously have a significant effect on wom communication, but partially only healthcare service quality does not have significant influence on WOM communication. This model can provide an alternativeand enrich literature on WOM communication, especially in healthcare industries.

The managerial implication of this study are that hospital management must provide maximum effort on service quality, hospital image, experience economic and perception simultaneously so WOM communication in BPJS patients will increase significantly, because no matter how good the quality of service is attempted, if it does not pay attention to the image quality of the hospital and the application of the experience economic concept, so as to create a good patient perception, then the effect will not be significant on WOM communication carried out by patients

\section{Research Limitations and Recommendations for further research}

This study only examines the effect of variable variables on WOM communication, it is necessary to examine how healthcare service quality, hospital image and experience economic and patient perception and WOM communication can have implications for profit and consistency of hospitals in the community, and also be done in other areas and also in other types of hospitals. Further research is proposed by exploring independent variables, because the $\mathrm{R}^{2}$ value generated in this study is only $48 \%$, meaning that there are still variables that have not been explored.

\section{REFERENCES}

Ahmed, S., Tarique, K. M., \& Arif, I. (2017). service quality, patient satisfaction and loyalty in the Bangladesh healtcare sector. International Journal of Health Care Quality Assurance, 30(5). https://doi.org/10.1108/

Akhade, G. N., Jaju, B., \& Lakhe, R. R. (2016). Healthcare Service Quality Dimensions in Various Countries. IOSR Journal of Nursing and Health Science Ver. I, 5(3), 2320-1940. https://doi.org/10.9790/19590503017076

Amin, M., \& Nasharuddin, S. Z. (2013). Hospital service quality and its effects on patient satisfaction and behavioural intention. Clinical Governance, 18(3), 238-254. https://doi.org/10.1108/CGIJ-05-2012-0016

Arboleda Arango, A. M. (2015). Healthcare plans and consumer perceptions of healthcare institutions. Revista de Salud Pública, 17(1), 12-21. https://doi.org/10.15446/rsap.v17n1.36202

Bouzaabia, R., Bouzaabia, O., \& Capatina, A. (2013). Retail logistics service quality: a cross-cultural survey on customer perceptions. International Journal of Retail \& Distribution Management, 41(8), 627-647. https:// doi.org/10.1108/IJRDM-02-2012-0012

Byram, R. N. J. A. (2016). Healthcare service quality effect on patient satisfaction and behavioural intention: empirical evidence from India. International Journal of Pharmaceutical and Healthcare Marketing, 10(1). https://doi.org/10.1108/IJPHM-07-2014-0043

American Research Journal of Business and Management

Page 15 
The Effect of Healthcare Service Quality, Hospital Image and Experience Economic on Worth of Mouth through BPJS Patient PerceptionType B Hospital in West Java

Campos, D. F., Bezerra, R., Filho, N., \& Castro, F. N. (2016). International Journal of Health Care Quality Assurance For Service Quality In Public Health Clinics: Perceptions Of Users And Health Professionals. International Journal of Healt Care Quality Assuraance. https://doi.org/10.1108/IJHCQA-09-2016-0140

Cavallone, M., Magno, F., \& Zucchi, A. (2017). Improving service quality in healthcare organisations through geomarketing statistical tools. The TQM Journal, 29(5), 690-704. https://doi.org/10.1108/TQM-12-20160104

Cham, T. H., Lim, Y. M., Aik, N. C., \& Tay, A. G. M. (2016). Antecedents of hospital brand image and the relationships with medical tourists' behavioral intention. International Journal of Pharmaceutical and Healthcare Marketing, 10(4), 412-431. https://doi.org/10.1108/IJPHM-02-2016-0012

Chang, C.-W., Tseng, T.-H., \& G. Woodside, A. (2013). Configural algorithms of patient satisfaction, participation in diagnostics, and treatment decisions ' influences on hospital loyalty. Journal of Services Marketing, 27(2), 91-103. https://doi.org/10.1108/08876041311309225

Chang, S. (2018). Experience economy in hospitality and tourism: Gain and loss values for service and experience. Tourism Management, 64, 55-63. https://doi.org/10.1016/j.tourman.2017.08.004

Choi, B. J., \& Kim, H. S. (2013). The impact of outcome quality, interaction quality, and peer-to-peer quality on customer satisfaction with a hospital service. Managing Service Quality, 23(3), 188-204. https://doi. org/10.1108/09604521311312228

Choudhury, K. (2014). Service quality and word of mouth: a study of the banking sector. International Journal of Bank Marketing, 32(7), 612-627. https://doi.org/10.1108/IJBM-12-2012-0122

Dang, V. M., François, P., Batailler, P., Seigneurin, A., Vittoz, J. P., Sellier, E., \& Labarère, J. (2014). Medical recordkeeping and patient perception of hospital care quality. International Journal of Health Care Quality Assurance, 27(6), 531-543. https://doi.org/10.1108/IJHCQA-06-2013-0072

Debajani, \& Tathagata. (2016). "Hospital service quality and its effects on patient satisfaction and behavioural intention", Clinical Governance: An. International Journal of Health Care Quality Assurance Iss International Journal of Health Care Quality Assurance Iss International Journal Iss International Journal of Health Care Quality Assurance, 29(5), 600-613. Retrieved from http://dx.doi.org/10.1108/IJHCQA-05-2015-0068

Debata, B. R., Patnaik, B., Mahapatra, S. S., \& Sree, K. (2015). Interrelations of service quality and service loyalty dimensions in medical tourism. Benchmarking: An International Journal, 22(1), 18-55. https://doi. org/10.1108/BIJ-04-2013-0036

Dian, Y., \& Limantara, P. (2017). Pengaruh Customer Perception Terhadap Minat Beli Konsumen Melalui Multiattribute Attitude Model Pada Produk Makanan Organik. Manajemen Pemasaran, 11(2), 69-77. https://doi.org/10.9744/pemasaran.11.2.69

Duku, S. K. O., Nketiah-Amponsah, E., Janssens, W., \& Pradhan, M. (2018). Perceptions of healthcare quality in Ghana: Does health insurance status matter? PLOS ONE, 13(1), 1-18. https://doi.org/10.1371/journal. pone.0190911

Edward Baldwin, A. (2014). Service quality in an Australian private dental network. The TQM Journal, 26(4), 360-367. https://doi.org/10.1108/TQM-01-2014-0008

Ejaz, A., Kim, Y., Winner, M., Page, A., Tisnado, D., Dy, S. E. M., \& Pawlik, T. M. (2016). Associations Between Patient Perceptions of Communication, Cure, and Other Patient-Related Factors Regarding Patient-Reported Quality 
The Effect of Healthcare Service Quality, Hospital Image and Experience Economic on Worth of Mouth through BPJS Patient PerceptionType B Hospital in West Java

of Care Following Surgical Resection of Lung and Colorectal Cancer. Journal of Gastrointestinal Surgery, 20(4), 812-826. https://doi.org/10.1007/s11605-015-3035-5

Fatima, T., Malik, S. A., \& Shabbir, A. (2017). Hospital Healthcare Service Quality , Patient Satisfaction and Patient Loyalty : An Investigation in context of Private Healthcare Systems of Pakistan.

Gibbons, H. M., Owen, R., \& Heller, T. (2016). Perceptions of health and healthcare of people with intellectual and developmental disabilities in medicaid managed care. Intellectual and Developmental Disabilities, 54(2), 94-105. https://doi.org/10.1352/1934-9556-54.2.94

Ha, J., \& Jang, S. (Shawn). (2012). The effects of dining atmospherics on behavioral intentions through quality perception. Journal of Services Marketing, 26(3), 204-215. https://doi.org/10.1108/08876041211224004

Hapsari, R., Clemes, M. D., \& Dean, D. (2017). The impact of service quality, customer engagement and selected marketing constructs on airline passenger loyalty. International Journal of Quality and Service Sciences, 9(1), 21-40. https://doi.org/10.1108/IJQSS-07-2016-0048

Hendarwati, A. (2016). Analisis Pengaruh Dimensi Word Of Mouth Communication Terhadap Keputusan Pembelian Sajian Kuliner Lapak Angkringan (Studi pada Konsumen Penikmat Sajian Kuliner Lapak Angkringan di Wilayah Mangkubumi Yogyakarta). AKMENIKA Jurnal Akutansi Dan Manajemen, 13(1), 593609.

Hinson, R., Owusu-Frimpong, N., \& Dasah, J. (2011). Brands and service-quality perception. Marketing Intelligence \& Planning, 29(3), 264-283. https://doi.org/10.1108/02634501111129248

Izadi, A., JAHANI, Y., Rafiei, S., Masoud, A., \& Vali, L. (2016). Evaluating health service quality: using importance performance analysis. International Journal of Health Care Quality Assurance, 30(7), 656-663.

Jalilvand, M. R., Salimipour, S., Elyasi, M., \& Mohammadi, M. (2017). Factors influencing word of mouth behaviour in the restaurant industry. Marketing Intelligence \& Planning, 35(1), 81-110. https://doi.org/10.1108/MIP02-2016-0024

Kemp, E., Jillapalli, R., \& Becerra, E. (2014). Healthcare branding: developing emotionally based consumer brand relationships. Journal of Services Marketing, 28(2), 126-137. https://doi.org/10.1108/JSM-08-2012-0157

Kobayashi, H., Takemura, Y., \& Kanda, K. (2011). Patient perception of nursing service quality; an applied model of Donabedian's structure-process-outcome approach theory. Scandinavian Journal of Caring Sciences, 25(3), 419-425. https://doi.org/10.1111/j.1471-6712.2010.00836.x

Kondasani, R. K. R., \& Panda, R. K. (2015). Customer perceived service quality, satisfaction and loyalty in Indian private healthcare. International Journal of Health Care Quality Assurance, 28(5), 452-467. https://doi. org/10.1108/IJHCQA-01-2015-0008

Kotler, P. (1994). Marketing Management, 8th ed. Englewood Cliffs, NJ: Prentice-Hall.

Kotler, Philip and Keller, Kevin Lane. 2012. Marketing Management. Prentice Hall

Koteswara Rao Kondasani, R., Kumar, R., Amin, M., \& Zahora Nasharuddin, S. (2015). "Hospital service quality and its effects on patient satisfaction and behavioural intention." International Journal of Health Care Quality Assurance International Journal of Health Care Quality Assurance Clinical Governance: An International Journal, 28(3), 452-467. Retrieved from http://dx.doi.org/10.1108/IJHCQA-06-2014-0074

Lupton, D. (2013). The commodification of patient opinion: the digital patient experience economy in the age of big data. Sociology of Health \& Illness, 36(6), 856-869. https://doi.org/10.1111/1467-9566.12109 
The Effect of Healthcare Service Quality, Hospital Image and Experience Economic on Worth of Mouth through BPJS Patient PerceptionType B Hospital in West Java

Manthiou, A., (Ally) Lee, S., (Rebecca) Tang, L., \& Chiang, L. (2014). The experience economy approach to festival marketing: vivid memory and attendee loyalty. Journal of Services Marketing, 28(1), 22-35. https://doi. org/10.1108/JSM-06-2012-0105

Martin, S. (2017). Word-of-mouth in the health care sector: a literature analysis of the current state of research and future perspectives. International Review on Public and Nonprofit Marketing, 14(1), 35-56. https://doi. org/10.1007/s12208-016-0154-y

Mehmetoglu, M., \& Engen, M. (2011). Pine and Gilmore's Concept of Experience Economy and Its Dimensions: An Empirical Examination in Tourism. Journal of Quality Assurance in Hospitality and Tourism, 12(4), 237255. https://doi.org/10.1080/1528008X.2011.541847

Mohammad Mosadeghrad, A. (2013b). Healthcare service quality: towards a broad definition. International Journal of Health Care Quality Assurance. https://doi.org/10.1108/09526861311311409

Narang, R., Polsa, P., Soneye, A., \& Fuxiang, W. (2015). Impact of hospital atmosphere on perceived health care outcome. International Journal of Health Care Quality Assurance, 28(2), 129-140. https://doi.org/10.1108/ IJHCQA-12-2013-0142

Nikoloski, Z., \& Mossialos, E. (2013). Corruption, inequality and population perception of healthcare quality in Europe. BMC Health Services Research, 13(1). https://doi.org/10.1186/1472-6963-13-472

Obamiro, J. K., Ogunnaike, O. O., \& Osibanjo, O. A. (2014). Organizational Citizenship Behaviour, Hospital Corporate Image and Performance. Journal of Competitiveness, 6(1), 36-49. https://doi.org/10.7441/ joc.2014.01.03

Oh, H., Fiore, A. M., \& Jeoung, M. (2007). Measuring experience economy concepts: Tourism applications. Journal of Travel Research, 46(2), 119-132. https://doi.org/10.1177/0047287507304039

Owusu Kwateng, K., Lumor, R., \& Acheampong, F. O. (2017). Service quality in public and private hospitals: A comparative study on patient satisfaction. International Journal of Healthcare Management, $0(0), 1-8$. https://doi.org/10.1080/20479700.2017.1390183

Pai, Y. P., Professor, A., Chary, S. T., Com, M., Yogesh Pai, R., \& Professor, A. (2017). Patient-perceived hospital service quality: an empirical assessment. International Journal of Healt Care Quality Assuraance. https:// doi.org/10.1108/IJHCQA-04-2017-0064

Parasuraman, A., V. A. Zeithaml, and L. L. Berry (1988). "SERVQUAL: A Multiple-Item Scale for Measuring Customer Perceptions of Service." Journal of Retailing, 64 (Spring): 12-37

Patel, M. N., \& Bhatt, D. N. K. H. (2017). an Empirical Study on Integration of Servqual and Kano Model for Measuring Service Quality of Hospitals in Ahmedabad. Indian Journal of Commerce \& Management Studies, VIII(3), 77-95. https://doi.org/10.18843/ijcms/v8i3/10

Pine, B. J., \& Gilmore, J. H. (1998). Welcome To The Experience Economy.: EBSCOhost. Harvard Business Review, 76(4), 97-105. https://doi.org/Article

Polsa, P., Fuxiang, W., Sääksjärvi, M., \& Shuyuan, P. (2013). Cultural values and health service quality in China. International Journal of Health Care Quality Assurance International Journal of Health Care Quality Assurance Iss International Journal of Health Care Quality Assurance, 26(5), 55-73. Retrieved from http://dx.doi. org/10.1108/09526861311288640 
The Effect of Healthcare Service Quality, Hospital Image and Experience Economic on Worth of Mouth through BPJS Patient PerceptionType B Hospital in West Java

Prakash, G. (2015). Steering healthcare service delivery : a regulatory perspective. International Journal of Healthcare Quality Assurance, 28(2), 173-192. Retrieved from http://dx.doi.org/10.1108/IJHCQA-032014-0036

Putra, R. A., Hartoyo, H., \& Simanjuntak, M. (2017). The Impact of Product Quality, Service Quality, and Customer Loyalty Program perception on Retail Customer Attitude. Independent Journal of Management \& Production, 8(3), 1116. https://doi.org/10.14807/ijmp.v8i3.632

Rahman, M. S., Mannan, M., Hossain, M. A., \& Zaman, M. H. (2018). Patient's behavioral intention: public and private hospitals context. Marketing Intelligence \& Planning, MIP-08-2017-0155. https://doi.org/10.1108/ MIP-08-2017-0155

Saunders, S., Rod, M., Mostafa, M., Manzano, A., \& Pawson, R. (2012). Development and testing of three unique scales measuring the brand image of nursing. Journal of Health Organization and Management, 28(2), 1-34. https://doi.org/10.1108/17506121211216905

Sekaran, U., \& Bougie, R. (2016). Research Methods For Business : A Skill Building Approach, $7^{\text {th }}$ Edition. United Kingdom : John Wiley \& Sons Ltd.

Shabbir, A., Malik, S. A., \& Malik, S. A. (2016a). Measuring patients' healthcare service quality perceptions, satisfaction, and loyalty in public and private sector hospitals in Pakistan. International Journal of Quality \& Reliability Management, 33(5), 538-557. https://doi.org/10.1108/IJQRM-06-2014-0074

Sivadas, E., \& Jindal, rupinder paul. (2017). Alternative measures of satisfaction and word of mouth. Journal of Service Marketing, 31(2).

Sliwa, M., \& James O'Kane. (2016). Service quality measurement : appointment systems in UK GP practices. International Journal of Health Care Quality Assurance, 24(6), 441-452.

Thoa, N. T. M., Thanh, N. X., Chuc, N. T. K., \& Lindholm, L. (2013). The impact of economic growth on health care utilization: A longitudinal study in rural Vietnam. International Journal for Equity in Health, 12(1), 1. https://doi.org/10.1186/1475-9276-12-19

Wu, P. C. S., \& Wang, Y. (2011). The influences of electronic word-of-mouth message appeal and message source credibility on brand attitude. Asia Pacific Journal of Marketing and Logistics, 23(4), 448-472. https://doi. org/10.1108/13555851111165020

Zeithaml, V. A.,Bitner, M. J., \& Gremler, D. D. (2012). Service Marketing : McGraw-Hill

Zhang, M., Hu, M., Guo, L., \& Liu, W. (2016). Engagement, and Word-of-mouth Intention on Online Brand Communities : The Perspective of Service Ecosystem. Internet Research.

Citation: Darnus Djaya , Farida Jasfar, Hamdy Hady. "The Effect of Healthcare Service Quality, Hospital Image and Experience Economic on Worth of Mouth through BPJS Patient PerceptionType B Hospital in West Java". American Research Journal of Business and Management. 2018; 4(1): 1-19.

Copyright (C) 2018 Darnus Djaya , Farida Jasfar, Hamdy Hady. This is an open access article distributed under the Creative Commons Attribution License, which permits unrestricted use, distribution, and reproduction in any medium, provided the original work is properly cited. 